Editorial 

Aloma 2019, 37(2), 9-10

Revista de Psicologia, Ciències de l'Eduació i de l'Esport

ISSN: 1138-3194

(C)Facultat de Psicologia, Ciències de l'Educació i de l'Esport Blanquerna

Universitat Ramon Llull

\title{
Active learning through flipped classroom
}

Salvador Montaner Villalba \& Jesús García Laborda

Guest editors

\begin{abstract}
A
we near the end of the second decade of the 21 st century, education has evolved to the point that both learners' and teachers' roles have changed significantly. Thus, the learners have become the authentic protagonists of their own learning process and, at the same time, teachers have taken on a role as learners' guides and advisors. From this premise, a series of new educational methodologies have emerged, all of them with the main purpose of motivating learners and granting them the role of protagonists. Flipped Learning or the Flipped Classroom has proved to be one of the most relevant active educational methodologies of the last 15 years. Moreover, Flipped Learning is nowadays more possible than ever due to the increasing use of the Information and Communication Technologies in Education. ICT, of course, is also one of the main editorial focuses of Aloma.

This monographic issue is the result of various types of research which have been carried out taking into consideration the premises of Flipped Classroom. In the first paper, Sosa Díaz and Narciso present a qualitative research analysis of a Flipped Classroom teaching intervention in Higher Education. Their research tool to investigate the Flipped Classroom's impact consists of data collection based upon a structured interview, and they use a data analysis strategy based on Grounded Theory. This method allows them to acquire knowledge in a practical manner. The results of the study show that the use of the method contributes to academic excellence and stimulates the development of key competences such as organizational skills, autonomy, responsibility, etc.

Next, Sánchez-Compaña and Sánchez-Cruzado explain the design and validation process of a questionnaire which allows educators to assess their own use of the Flipped Learning model. The questionnaire is designed to assess the degree to which these teaching practices meet the general standards established for this
\end{abstract}

model. In the design phase, the authors conducted a thorough review of a previously existing, taking as their frame of reference the general standards determined by international experts on creating and applying the Flipped Learning model. The validation phase consisted of two procedures: firstly, 12 experts gave their suggestions and feedback, many of which were incorporated into the design of a pilot version of the questionnaire, which was then administered to participants in the second phase. In this second phase, the researchers analyse whether the questionnaire meets the minimum requirements for validity and reliability through the analysis of the answers offered by the 76 people who participated in the pilot experience.

The third paper, by Galindo-Domínguez, analyses the effectiveness of the Flipped Classroom methodology on Primary Education students' self-concept. The sample was made up of two groups. There were 437 learners in the control group and 385 learners in the experimental group. The latter group worked with the Flipped Classroom model. Moreover, this same author, in the sixth paper, analyses the effect of the Flipped Classroom on the social context of the classroom in Primary Education. The sample was made up of a control group of 61 learners and a treatment group of 48 learners who worked with the Flipped Classroom method.

In the fourth article, Marqués-Molías, PalauMartín, Usart and Morilla focus on fifth and sixth grade primary school students, with the main aim of comparing a teaching proposal for korfball using a Flipped Classroom methodology (treatment group) with a control group. The outcomes were obtained using three different research tools and at three different moments during the term. The data show significant differences between the two groups in terms of their learning of korfball knowledge and, especially, the extent to which they knew the rules and used strategy during game play. The learners 
who had used the Flipped Classroom method attained higher marks.

Next, the fifth paper, written by Ojando, Simón, Prats, Martínez Felipe, Santaolalla and Torres, presents a training experience on the Flipped Classroom for university professors. The training programme was part of a strategic teaching innovation project at Pontificia Comillas University. The authors describe the implementation of a training experience in the Flipped Classroom method and a subsequent evaluation based on the learners' assessment gathered using a questionnaire. The findings show that the professors experienced some time and space difficulties in the design, creation and implementation of tasks, but that learners showed interest in new ways of learning.

Finally, in the sixth paper Galindo-Dominguez examines the effect of the Flipped Classroom on the social climate in the classroom. In this paper, the author compares the results from a control group with those of an experimental group. Both groups completed a survey on perceived social climate at the beginning and, again, at the end of the intervention. The outcomes showed that the treatment group did not present significant differences with respect to the control group in any of the dimensions analysed, with the exception of the regulatory context, for which the experimental group's scores decreased to a lesser degree than those of the control group. This methodology did not help to improve the social climate in the classroom.

This monograph on the Flipped Classroom is indeed a volume which will be of use and interest not only to active teachers, but also to teacher trainees and future researchers from a range of disciplines interested in furthering their knowledge of the Flipped Classroom. That is why we are convinced that the readers will both learn from and enjoy the well-documented research in this issue. We believe this research will provide our readers with a firm empirical basis upon which to improve both their approach to teaching and their personal action-research.

Barcelona, 2019

Salvador Montaner Villalba (UNED) https://orcid.org/0000-0002-2742-5338

Jesús García Laborda (UAH) https://orcid.org/0000-0003-0125-4611 
Noman 2019, 37(2), 11-12

Revista de Psicologia, Ciències de l'Eduació i de l'Esport

ISSN: 1138-3194

(C)Facultat de Psicologia, Ciències de l'Educació i de l'Esport Blanquerna

Universitat Ramon Llull

\section{Aprendizaje activo a través de la clase inversa}

Salvador Montaner Villalba \& Jesús García Laborda

Editores invitados

$\mathrm{C}$

asi al término de la segunda década del siglo XXI, la educación ha evolucionado hasta el punto de que el rol tanto del alumnado como del profesorado ha evolucionado significativamente. Así, el alumno se ha convertido en el auténtico protagonista en el proceso de su propio aprendizaje al tiempo que el profesor desempeña el papel de guía y acompañante del alumnado. A partir de esta premisa, han ido surgiendo paulatinamente diversas metodologías activas con el fin de motivar al alumnado, poniéndole en el centro del aprendizaje. El Aprendizaje Inverso es una de ellas que ha adquirido una inmensa relevancia en los últimos 15 años. Además, el Aprendizaje Inverso es, en la actualidad, cada vez más posible debido al uso in crescendo de las Tecnologías de la Información y la Comunicación en la educación, siendo las TIC una de las diversas líneas editoriales más relevantes de la revista Aloma.

En este respecto, este monográfico es fruto de diversas investigaciones que se han llevado a cabo teniendo en consideración las premisas del Aprendizaje Invertido. En el primer trabajo, Sosa Díaz y Narciso presentan una investigación de corte cualitativo, cuyo objetivo es analizar una práctica de Flipped Classroom en la Educación Superior y determinar el impacto que supone en el alumnado la implementación de dicho modelo pedagógico en su proceso formativo a partir de un instrumento de recogida de datos basado en una entrevista estructurada, y una estrategia de análisis de datos basada en la Teoría Fundamentada favoreciendo la adquisición de conocimientos de manera práctica y aumentando así el rendimiento académico al tiempo que estimula el desarrollo de diversas competencias claves, a saber, la capacidad de organización, autonomía, responsabilidad, etc.

A continuación, Sánchez-Compaña y Sánchez-Cruzado exponen los pasos seguidos para el diseño y la validación de un cuestionario que permita evaluar al profesorado que emplea el modelo Flipped Learning, valorando cuánto se adecúan dichas prácticas a los estándares generales establecidos para dicho modelo. Para la fase del diseño, se ha partido de un cuestionario previo, realizando una profunda revisión del mismo, y teniendo como referencia los estándares generales determinados por las personas expertas en la creación y aplicación del modelo Flipped Learning a nivel internacional. La fase de validación se realizó mediante dos procedimientos: por un lado, mediante una consulta a 12 expertos, cuyas sugerencias fueron analizadas y consideradas para el diseño de un cuestionario piloto, con el que se ha abordado la segunda fase, en la que se analiza si el cuestionario cumple unos criterios mínimos de validez y fiabilidad, mediante el análisis de las respuestas ofrecidas por las 76 personas que participaron en la experiencia piloto.

La tercera investigación, por Galindo-Domínguez, analiza la efectividad del Flipped Classroom sobre el autoconcepto de estudiantes de Magisterio. La muestra fue conformada, por un lado, por 437 estudiantes (grupo control) y por 385 estudiantes (grupo experimental), sometiéndose este grupo a una intervención Flipped Classroom. Además, dicho autor en el sexto trabajo de este monográfico pretende analizar el efecto del Flipped Classroom sobre el clima social del aula en Educación Primaria, estando la muestra conformada, por un lado, por 61 participantes en grupo control y, por otro, 48 en grupo experimental, sometiéndose este grupo a una intervención Flipped Classroom.

En el cuarto artículo, Marqués-Molías, PalauMartín, Usart y Morilla se centran en el tercer ciclo de educación primaria, con el objetivo principal de comparar una propuesta didáctica del Korfball a través del $F C$ con un grupo control. Los datos se obtuvieron a partir de tres instrumentos y en tres momentos del trimestre, y muestran diferencias significativas en el aprendizaje de conocimientos en torno al Korfball, 
concretamente, en las normas y la aplicación de la estrategia del juego durante su práctica, donde los estudiantes con $F C$ puntúan más alto.

Luego, el quinto trabajo, elaborado por Ojando, Simón, Prats, Martínez Felipe, Santaolalla y Torres, se centra en una experiencia de formación en Flipped Classroom dirigida a los docentes universitarios, enmarcándose esta experiencia en un proyecto estratégico de innovación docente de la Universidad Pontificia Comillas. Se describe la implementación de una experiencia de formación sobre el modelo de la Flipped Classroom dirigida al profesorado universitario y su posterior evaluación a partir de la valoración de los participantes mediante un cuestionario. Los resultados apuntan que el profesorado presentó algunas dificultades de tiempos y espacios para diseñar, crear e implementar actividades en el aula mientras, por otra parte, el alumnado manifestó interés por disponer de nuevas formas de aprendizaje.

Por último, en la sexta investigación, GalindoDomínguez pretende investigar el efecto del Flipped Classroom sobre el clima social del aula. En este trabajo el autor analiza los resultados a partir de tanto una muestra en grupo control como de grupo experimental, a cuyos grupos se les pasó una escala de clima social percibido tanto al comienzo como al término de la experimentación. Los resultados indicaron que el gru- po experimental no presentó, en ninguna de las dimensiones analizadas, diferencias significativas con respecto al grupo control si bien, en el contexto regulativo, su empeoramiento fue más leve que el del grupo control, lo cual no evidencia que el Flipped Classroom mejore significativamente el clima social del aula.

El presente monográfico en torno al Flipped Classroom es, sin duda alguna, un volumen que puede resultar útil e interesante no sólo para profesores en activo sino también para futuros profesores que aún se están formando en las facultades de educación, así como a futuros investigadores que tienen interés en profundizar en torno al Flipped Classroom en diversas líneas de investigación. En este sentido, estamos convencidos que el lector aprenderá y disfrutará a la vez de un contenido bien fundamentado que le servirá como una primera piedra para mejorar su práctica docente y su investigación en acción personal.

Barcelona, 2019

Salvador Montaner Villalba (UNED) https://orcid.org/0000-0002-2742-5338

Jesús García Laborda (UAH) https://orcid.org/0000-0003-0125-4611 